\title{
ГЕНДЕРНЫЕ ОСОБЕННОСТИ ГОРМОНАЛЬНОГО ПРОФИЛЯ ЮНЫХ СПОРТСМЕНОВ ВЫСОКОЙ КВАЛИФИКАЦИИ
}

\section{1,2* Окороков П.Л., ${ }^{1}$ Аксенова Н.В., ${ }^{1}$ Бабаева Е.В., ${ }^{1}$ Афанасьев А.Н.}

${ }^{1}$ Федеральный научно-клинический центр детей и подростков ФМБА, Москва, Россия

${ }^{2}$ Национальный медицинский исследовательский центр эндокринологии, Москва, Россия

Эндокринная система играет ключевую роль в адаптации юных спортсменов к высоким физическим и психо-эмоциональным нагрузкам, имеющим место в спорте высших достижений. Секреция некоторых гормонов имеет ярко выраженную гендерную специфичность.

Цель работы: оценить показатели гормонального профиля юных спортсменов высокой квалификации

Материалы и методы: Проанализированы данные 1552 амбулаторных карт юных спортсменов высокой квалификации (907 юноши; 645 девушки) в возрасте от 11 до 17 лет, по 28 видам спорта, прошедших углубленное медицинское обследование (УМО) в соответствии с приказом Минздрава РФ №134-Н. Проведено исследование тиреотропного гормона (ТТГ), свободного Т4 (Т4 св.), антител к тиропероксидазе (АТ к ТПО), кортизола, соматотропного гормона (СТГ) и общего тестостерона методом иммунохемилюминесцентного анализа.

Результаты и обсуждение: Частота отклонений гормонального профиля от нормы у юных спортсменов высокой квалификации составляет 30,7\%. У юношей гормональные изменения выявляются в $36,4 \%$ случаев; у девушек - в $22,8 \%$ случаев. Наиболее часто в детско-юношеском спорте высших достижений отмечается повышение уровня кортизола (>690 нмоль/л) -13,2\%. Повышение общего тестостерона регистрируется у 10,7\% обследованных; гиперсекреция СТГ (>12,1 нг/мл) - в $3,7 \%$, повышение ТТГ ( $>5,5$ мЕд/л) при нормальном уровне Т4 св. и отсутствии повышения АТ к ТПО - в $3,1 \%$.

У юношей спортсменов на первом месте по частоте встречаемости стоит повышение общего тестостерона сыворотки (>27,5 нмоль/л), выявленное у 142 спортсменов, что составило 15,6\%. Повышение кортизола определяется у 13,1\% обследованных, повышение ТТГ - у 3,2\%, повышение СТГ - у 2,2\%. Снижение уровня общего тестостерона (<9 нмоль/л для возрастной группы 15-17 лет) выявлено у 12 юношей спортсменов (1,3\% обследованных лиц мужского пола).

У девушек спортсменок в гормональном профиле чаще других выявляется повышение кортизола сыворотки (13,5\%), на втором месте - повышение СТГ (5,9\%). Повышение общего тестостерона сыворотки (>4,45 нмоль/л) определяется у 4,9\% юных спортсменок, повышение ТТГ - в 3,2\% случаев.

Заключение: Гормональные изменения в юношеском спорте высших достижений на треть чаще регистрируются у юношей по сравнению с девушками, преимущественно за счет повышения общего тестостерона. Для девушек спортсменок более характерна гиперсекреция базального СТГ и повышение уровня кортизола. Повышение ТТГ встречается с одинаковой частотой у высококвалифицированных спортсменов обоего пола. 